\title{
Effect of Sport Training and Education on Q Angle in Young Males and Females
}

\author{
Orhan Ahmet Şener ${ }^{1}$, Mehmet Durmaz ${ }^{1}$ \\ ${ }^{1}$ Faculty of Sport Sciences, Selcuk University, Konya, Turkey \\ Correspondence: Orhan Ahmet Şener, Faculty of Sport Sciences, Selcuk University, Konya, Turkey.
}

Received: March 14, 2019

Accepted: May 7, 2019

Online Published: May 15, 2019

doi:10.11114/jets.v7i7.4133

URL: https://doi.org/10.11114/jets.v7i7.4133

\begin{abstract}
The purpose of this study investigation of the effect of sport training and education on Q angle in young males and females. The Quadriceps Q angles of 240 female and 600 male subject were measured in both supine and standing positions by goniometer. It was used t-tests for statistical analyses. In this study, the average age was found to be 19.16 for women and 21.120 for men. The vast majority of participants are in the 17-22 age range. In this study, was found the mean $\mathrm{Q}$ angle of female and male subjects at supine position $15.71^{\circ}$ and $13.02^{\circ}$. On the other hand $\mathrm{Q}$ angle of female and male subjects at standing position were $17.05^{\circ}$ and $14.04^{\circ}$ respectively. The difference between mean $\mathrm{Q}$ angle of female and male subject was statistically significant $(\mathrm{p}<0.001)$. Between undergraduate study group and non-undergraduate group wasn't differences Standing Q angle and Supine Q angle statistically significant ( $>>0.05)$. Finally, the mean dominant knee $\mathrm{Q}$ angle of young females and males seemed to be in normal range. The high value of the knee $\mathrm{Q}$ angle of the dominant leg should be considered to be greater than 17 for males and 20 for females. The effect of physical activity on Q-angle should be investigated more extensively. It is thought that sport education has a decreasing effect on $\mathrm{Q}$ angle.
\end{abstract}

Keywords: Q angle, female, male

\section{Introduction}

The $\mathrm{Q}$ angle is the angle subtended by the intersection of a line drawn from the anterior superior iliac spine to the Centre of the patella and another line connecting the Centre of the patella to the Centre of the tibia tuberosity (Grelsamer et al., 2005). Genus is largest joint of the body, so protecting of it from trauma is difficult. For this reason sport physicians and experts on biomechanics pay attention to this subject. The $\mathrm{Q}$ angle is the acute angle formed by lines drawn from anterior superior iliac spine to the center of patella, and from to center of the patella to the tibal tuberosity (Woodland and Francis, 1992). The Q angle has been used for the diagnosis of many diseases, for the comparison of normal and injured knees, and for the evaluation of improvements after therapies. This angle highlights knee joint mechanism, settlement of dentures, and identification of relationships among structural factors and sport injuries (Kishali et al., 2004). In addition to causing knee injuries, Q angle is also reported to be affected by a great number physical factors and postural defects (Eliöz et al., 2015; Yılmaz et al., 2017).

Women have greater $\mathrm{Q}$ angles than men. The reason for higher $\mathrm{Q}$ angles in women is their pelvic base. Normal Q angle is 13 degrees for males and 18 degrees for females (Heggannavar et al., 2016). While there is no definitive diagnosis for the norm values of $\mathrm{Q}$ angle, on-normal values for this angle are thought to be 15 degrees and higher for men and 20 degrees and more for women. It is thought that when the $\mathrm{Q}$ angle exceeds the limit of 15-20 degrees, this causes disorders in the extensor mechanism of the knee and causes patellofemoral pain with the tendency of patella to slide to the lateral (İmamoğlu et al., 1995; Kishali et al., 2004). Deformities in the legs; brackets leg, X leg, asymmetric leg, increased Q angle can be counted. These can indirectly disrupt the aesthetic appearance. This is especially important for women. Although people who perform regular sports may have a more uniform body posture and appearance than sedentary people (Yamak et al., 2018), increased Q angle may have a negative effect. There is a wide variety of parameters on the body image. The self-confidence and inner peace reduction if the legs are $\mathrm{Q}$ and $\mathrm{X}$ or the $\mathrm{Q}$ angle is increased. In addition to correcting this angular disorder, other ways can be used. It has been stated that even the colors of garments create perceptual differences due to their effects on individuals (Yamaner and İmamoğlu, 2018). For example, clothes can close the shape of the legs. For example, white color means pure being, peacefulness and good 
character. It represents calm, relaxed and inner peace (Imamoglu, 2010; Imamoglu 2011; Imamoglu and Demirtas, 2017).

Women have consistently been found to have larger Q angles than men and are more often affected by patellofemoral problems. This is possibly due to an increased pelvic width, shorter femur length, or femoral neck ante version. Some investigators have found that $\mathrm{Q}$ angles greater than $15^{\prime \prime}$ for men and 20 " for women are more commonly associated with pathological conditions of the Patellofemoral joint. The role of Q angle in assessing lower-extremity injuries in sports has been documented (Emami et al., 2007; Fatahi et al., 2017). In the young subjects who entered the sports section exams, $\mathrm{Q}$ angle values were wondered. Their physical activity levels are different. Some are active athletes while others are less physically active.

The purpose of this study investigation of the effect of sport training and education on Q angle in young males and females.

\section{Method}

Measurements were made prior to entrance exam for special ability for physical education and sports department. Subjects were selected randomly and voluntarily for the measurement. Measurements were taken on two groups. One group special talent pre-exam candidate were 130 female and 370 male. The second group consists of 110 female and 230 male undergraduates with 1 year of sports education. The Q angles of 240 female and 600 male subjects whose average age is 20.15 were measured in both supine and standing positions by goniometer. The dominant leg Q-angles of the subjects were measured. Candidates who have taken the special ability test have been tested for branch, running and physical fitness. The participants had no history of lower limp injury or dysfunction. Knee Q angles of subject were measured when the knee and hip were in full extension, first in the supine and then in the standing positions. Before measurements, the borders of patella, the tibias tuberosity and the anterior superior iliac spine were located by careful palpation. A specially modified goniometer which had a longer arm $60 \mathrm{~cm}$ and a shorter arm $10 \mathrm{~cm}$ was used. The fulcrum of the goniometer was placed on the center of patella; the longer arm was directed to the anterior superior iliac spine and the shorter arm tibias tuberosity. The angle formed at the intersection of the two lines was measured as the Q-angle in degree (Losina et al., 2013). It was t-tests for statistical analyses. The participations were instructed to keep Quadriceps muscles and relaxed as possible. The level of significance was set at $\mathrm{p}<0.001$ and $\mathrm{p}<0.005$.

\section{Results}

Distribution of subjects according to age groups and gender are shown in Table 1. Subject's Q angle frequency distribution in the supine position are shown in Table 2. Subject's Q angle frequency distribution in the standing position are shown in Table 3. In Table 4, are shown evaluation of $\mathrm{Q}$ angle according to position and gender. In Table 5, shown $\mathrm{Q}$ angle non-normal high values.

Table 1. Distribution of subjects according to age groups and gender

\begin{tabular}{lcccccc}
\hline \multirow{2}{*}{ Aged (Year) } & \multicolumn{2}{c}{ Female } & \multicolumn{3}{c}{ Male } & \multicolumn{2}{c}{ Total } \\
\cline { 2 - 7 } & $\mathrm{n}$ & $\%$ & $\mathrm{n}$ & $\%$ & $\mathrm{n}$ & $\%$ \\
\hline $17-19$ & 134 & 55.83 & 156 & 26 & 290 & 34.53 \\
\hline $20-22$ & 87 & 36.25 & 295 & 49.17 & 382 & 45.48 \\
\hline $23-25$ & 13 & 5.42 & 112 & 18.67 & 125 & 14.88 \\
\hline 26 and high & 6 & 2.5 & 37 & 6.17 & 43 & 5.12 \\
\hline
\end{tabular}

Table 2. Subject's Q angle frequency distribution in the supine position

\begin{tabular}{|c|c|c|c|c|c|c|}
\hline \multirow{2}{*}{ Q angle } & \multicolumn{2}{|c|}{ Female } & \multicolumn{2}{|c|}{ Male } & \multicolumn{2}{|c|}{ Total } \\
\hline & $\mathrm{n}$ & $\%$ & $\mathrm{n}$ & $\%$ & $\mathrm{n}$ & $\%$ \\
\hline $6-8$ & 5 & 2.083 & 74 & 12.33 & 79 & 9.40 \\
\hline 9-11 & 31 & 12.92 & 173 & 28.83 & 204 & 24.29 \\
\hline $12-14$ & 76 & 31.67 & 147 & 24.5 & 223 & 26.55 \\
\hline $15-17$ & 51 & 21.25 & 85 & 14.17 & 136 & 16.19 \\
\hline $18-20$ & 35 & 14.58 & 52 & 8.67 & 87 & 10.36 \\
\hline $21-23$ & 25 & 10.47 & 39 & 6.5 & 64 & 7.62 \\
\hline $24-26$ & 14 & 5.83 & 21 & 3.5 & 35 & 4.17 \\
\hline 27 and high & 3 & 1.25 & 9 & 1.5 & 12 & 1.43 \\
\hline
\end{tabular}


Table 3. Subject's Q angle frequency distribution in the standing position

\begin{tabular}{|c|c|c|c|c|c|c|}
\hline \multirow{2}{*}{ Q angle } & \multicolumn{2}{|c|}{ Female } & \multicolumn{2}{|c|}{ Male } & \multicolumn{2}{|c|}{ Total } \\
\hline & $\mathrm{n}$ & $\%$ & $\mathrm{n}$ & $\%$ & $\mathrm{n}$ & $\%$ \\
\hline $6-8$ & 3 & 1.25 & 32 & 5.33 & 35 & 4.17 \\
\hline $9-11$ & 21 & 8.75 & 130 & 21.67 & 151 & 17.98 \\
\hline $12-14$ & 40 & 16.67 & 135 & 22.5 & 175 & 20.83 \\
\hline $15-17$ & 57 & 23.75 & 150 & 25 & 207 & 24.64 \\
\hline $18-20$ & 63 & 26.25 & 53 & 8.83 & 116 & 13.81 \\
\hline $21-23$ & 25 & 10.47 & 45 & 7.5 & 70 & 8.33 \\
\hline $24-26$ & 20 & 8.33 & 35 & 5.83 & 55 & 6.55 \\
\hline 27 and high & 11 & 4.58 & 20 & 3.33 & 31 & 3.69 \\
\hline \multicolumn{7}{|c|}{ Table 4. Evaluation of Q Angle according to position and gender } \\
\hline Variables & & Female & Male & $\mathrm{t}$ & & $\mathrm{p}$ \\
\hline Standing $Q$ angle & & 17.05 & 14.04 & $9.15^{* * *}$ & & 0.000 \\
\hline Supine Q angle & & 15.71 & 13.02 & $8.74 * *$ & & 0.001 \\
\hline Change in $\mathrm{Q}$ angle & & 1.34 & 1.02 & - & & - \\
\hline
\end{tabular}

$* * \mathrm{p}<0.001$

Table 5. Q angle values according to the state of sports training and education

\begin{tabular}{|c|c|c|c|c|}
\hline Variables & & Q angle for undergraduate study group & $\begin{array}{l}\text { Q angle for Non-undergraduate } \\
\text { group }\end{array}$ & $\mathrm{t}$ \\
\hline \multirow{2}{*}{ Standing $Q$ angle } & Female & 16.9 & 17.02 & 0.27 \\
\hline & Male & 14.02 & 14.06 & 0.16 \\
\hline \multirow{2}{*}{ Supine Q angle } & Female & 15.66 & 15.77 & 0.23 \\
\hline & Male & 13.01 & 13.03 & 0.15 \\
\hline \multicolumn{5}{|c|}{ Table 6. Q angle non-normal high values (Female $20^{\circ}$ and Male $17^{0}$ over) } \\
\hline Variables & & Female & $\mathrm{t}$ & $\mathrm{p}$ \\
\hline Standing $\mathrm{Q}$ angle $(\%)$ & & 23.38 & $2.25^{*}$ & 0.042 \\
\hline Supine $\mathrm{Q}$ angle $(\%)$ & & 17.55 & $2.46^{*}$ & 0.038 \\
\hline
\end{tabular}

${ }^{*} \mathrm{p}<0.05$

\section{Discussion}

In this study, the average age was found to be 19.16 for women and 21.120 for men. The vast majority of participants are in the 17-22 age range (Table 1). In this study, in the supine position $Q$ angle, the majority of the women were in the range of 12-20 degrees, while the males were in the range of 9-17 degrees (Table 2). In the standing position $\mathrm{Q}$ angle, the majority of the women were in the range of 12-23 degrees while the males were found in the range of 9-20 (Table 3). The $\mathrm{Q}$ angles of the subjects participating in the test have a wide distribution. When literature was reviewed, it was reported that the changes in $\mathrm{Q}$ angles differed based on the rate and intensity of physical activity and athletes who with more intense training programs showed lower results and it was stated that the results were associated with biomechanical factors such as femur length and pelvic length (Yilmaz et al.,2017). In one research project carried out in Turkey it was shown that the upper limit of Q angle is $18^{\circ}$ for men and $22^{\circ}$ for women (Kuru and Pekşen, 1993). It may be effective if the subjects in the study were more active than the subjects in the Kuru and Pekşen (1993) study.

Literature contains a variety of normal values ranging from $8^{0}$ to $17^{0}$, with women consistently having higher Q angles than men. Some reaches have established normal men $Q$ angles of $15^{\circ}$ and some have established them at $13.5^{\circ}$ (Kishali et al., 2004). Esmaeili et al., (2015) in a study Q angle greater than 15 degree were defined as high Q angle and Q angle 15 degree or less were defined as low $\mathrm{Q}$ angle based on the finding. Normal mean values for the $\mathrm{Q}$-angle are $13.5^{\circ}$ in healthy subjects between 18 and 35 years of age. Comparatively, women have a larger mean Q-angle of $15.8^{\circ}$ than men $\left(11.2^{\circ}\right)$, (Horton and Hall, 1989). Kopuz et al., (1995) in a study, was concluded that sports might be effective on the external pelvic measurements. In addition to sex, tibia, and femur length, pelvis width, dominant foot and shape of the feet may affect the Q angle (Kishali et al., 2004). Kishali et al, (2004) study, showed that the mean right and left knee Q angle of male athletes were $14.47^{\circ}$ and $13.69^{\circ}$ for the supine position, $13.25^{\circ}$ and $12.44^{\circ}$ for standing position. Again, the mean right and left knee $\mathrm{Q}$ angle of female athletes were $17.28^{\circ}$ and $16.90^{\circ}$ for the supine position, $16.57^{\circ}$ and $16.12^{\circ}$ for standing position. Sobjerg et al. (1987) in a study, have found the $\mathrm{Q}$ angle as $12.7^{0}$ in the supine position in males and $14.5^{0}$ in females. İmamoğlu et al., (1995) in a study, was found the mean Q angle of female students and male students at supine position $15.9^{\circ}$ and $12.93^{\circ}$. On the other hand $\mathrm{Q}$ angle of female and male students at standing position were $16.92^{\circ}$ and $13.91^{\circ}$ respectively. In this study, was found the mean $\mathrm{Q}$ angle of female and male subjects at Supine 
position $15.71^{\circ}$ and $13.02^{\circ}$. On the other hand $Q$ angle of female and male subjects at standing position were $17.05^{\circ}$ and $14.04^{0}$ respectively. The difference between mean $\mathrm{Q}$ angle of female and male subject was statistically significant $(\mathrm{p}<0.001)$.

İmamoğlu et al., (1995) found that the value of the abnormal Q angle is $17^{0}$ in males and $20^{\circ}$ in females. In the present study abnormal Q angles, at a ratio of approximately $17^{\circ}$ and $20^{\circ}$, is observed that there are approximately four quadrants. The results of the two studies are comparable. This situation can be caused by similar characteristics of participants who participate in the test and those who do sports. The literature clearly illustrates that women, on average, have larger Q angles than men do (Livingston and Mandigo, 1999). Teixeira at al., (2008) showed a bigger average of Q angle in female when compared to male subjects. Lower $\mathrm{Q}$ angles are associated with taller subjects, and because men are generally taller than women, they tend to have slightly lower $\mathrm{Q}$ angles. Although women have a wider pelvis in the traditional sense, the anterior superior iliac spine in women is no more lateralized than in men (Grelsamer et al., 2005). In this study, were found quadriceps $\mathrm{Q}$ angles for male smaller than women's.

Woodlands and Francis (1992) reported that the mean difference in $\mathrm{Q}$ angle for men in the supine as opposed to the standing position was $0.9^{\circ}$ while the mean difference in $\mathrm{Q}$ angle for women in the supine as opposed to the standing position was $1.2^{\circ}$. On average, this angle is three degrees greater in women than in men (17 degrees average for women compared with 14 degrees for men). It is thought that this increased angle places more stress on the knee joint, as well as leading to increased foot pronation in women (Quinn, 2018). In this study, found difference in Q angle for females in the supine as opposed to the standing position was $1.2^{\circ}$. It found while the mean difference in $\mathrm{Q}$ angle for Males in the supine as opposed to the standing position was $1.34^{\circ}$. Between undergraduate study group and non-undergraduate group wasn't differences Standing $Q$ angle and Supine $Q$ angle statistically significant ( $>0.05$ ). The $Q$ angle values of sports studying areas are lower than the other group, meaningless. Among the reading students, those who practice extreme training may be effective in the absence of this difference. It is thought that sport education has a decreasing effect on Q angle.

Activity level of the participants, their branches, race, and factors affecting muscular strength or tendon and joint stability were among the confounding factors that should be evaluated in future studies along with other effective factors in ankle, knee and pelvis regions (Moghadam et al., 2017). When the Q angle exceeds $15-20^{\circ}$ it is thought to contribute to knee extensor dysfunction and patellofemoral pain by increasing the tendency for lateral patellar malposition and, hence, altered patellofemoral stress distribution (Huberti and Hayes, 1994). In this study, when are accepted abnormal Q-angle above 20 degrees for female, this ratio is $17.55 \%$ in the spine position and $23.38 \%$ in the standing position. When Q angles of 17 degrees are considered abnormal on males, this ratio is $20.17 \%$ in the spine position and $25.79 \%$ in the standing position (Table 6). Q angle can be assumed to be 20 degrees for young females and 17 degrees for young males. In conclusion, the mean dominant knee $\mathrm{Q}$ angle of young females and males seemed to be in normal range. The high value of the knee $\mathrm{Q}$ angle of the dominant leg should be considered to be greater than 17 for males and 20 for females. The effect of physical activity on Q-angle should be investigated more extensively. It is thought that sport education has a decreasing effect on $\mathrm{Q}$ angle.

\section{References}

Eliöz, M., Tülin, A., Saç, A., \& Yamak, B. (2015). The Investigation of the Relationship between Some Physical Features with Q Angle in Athletes and Sedanteries, Journal of Sports and Performance Researches, 6(1), 58-65. https://doi.org/10.17155/spd.76168

Emami, M. J., Ghahramani, M. H., Abdinejad, F., \& Namazi, H. (2007). Q-angle: An invaluable parameter for evaluation of anterior knee pain. Arch Iran Med, 10, 24-26.

Esmaeili, A. M., Daneshmandi, H., \& Samami, N. (2015). The study of relationship malalignment knee and foot with injury in professional sprinters. Age (year), 22, 4-28.

Fatahi, A., Sadeghi, H., \& Ameli, M. (2017). Relationship between Q angle and knee injuries prevalence in elite volleyball players. Advances in Surgical Sciences, 5(4), 45. https://doi.org/10.11648/j.ass.20170504.11

Grelsamer, R. P., Dubey, A., \& Weinstein, C. H. (2005). Men and women have similar Q angles: a clinical and trigonometric evaluation. The Journal of bone and joint surgery. British volume,87(11), 1498-1501. https://doi.org/10.1302/0301-620X.87B11.16485

Heggannavar, A., Battula, L., \& Metgud, S. (2016). A correlation between leg-heel alignment, tibial torsion and Q angle amongst normal, overweight and obese individuals. Int $J$ Physiother Res, 4(3), 1530-1534. https://doi.org/10.16965/ijpr.2016.125

Horton, M. G., \& Hall, T. L. (1989). Quadriceps femoris muscle angle: normal values and relationships with gender and selected skeletal measures. Physical therapy, 69(11), 897-901. https://doi.org/10.1093/ptj/69.11.897 
Huberti, H. H., \& Hayes, W. C. (1984). Patellofemoral contact pressures. The influence of q-angle and tendofemoral contact. The Journal of bone and joint surgery. American volume,66(5), 715-724. https://doi.org/10.2106/00004623-198466050-00010

İmamoğlu, G. (2010). The Effect of Colors on Sportive Performance, Mustafa Kemal University Physical Education and Sports Science, 1(2), 40-52.

İmamoğlu, G. (2011). The Effect of Colors on Sportive Performance in Football, Ataturk University Physical Education and Sports Science, 7(2), 1-5.

İmamoğlu, G., \& Demirtaş, Ö. (2017). Investigation of students' views who receive art and religious training about body image. International Journal of Cultural and Social Studies, 3, 476-483.

İmamoğlu, O., Kuru, Ö., Doğan, A. A., \& Tutkun, E. (1995). Mean Quadriceps Angle at Supine and Standing Position of the Physical Education and Sports Departments Students, Karadeniz Medical Journal, 8(3), 126-130.

Kishali, N. F., İmamoglu, O., Burmaoglu, G., Atan, T., \& Yildirim, K. (2004). Q-angle values of elite soccer and taekwondo athletes. The Pain Clinic, 16(1), 27-33. https://doi.org/10.1163/156856904322858675

Kopuz, C., İmamoğlu, O., \& Dabak, Ş. (2010). Analysis of external pelvic measurements in female sports. Journal of Experimental and Clinical Medicine, 12(2), 119-126.

Kuru, O., \& Pekşen, Y. (1993). Quadriceps angle values in university students, Journal of Physical Therapy and Rehabilitation, 17, 210-212.

Livingston, L. A., \& Mandigo, J. L. (1999). Bilateral Q angle asymmetry and anterior knee pain syndrome. Clinical Biomechanics, 14(1), 7-13. https://doi.org/10.1016/S0268-0033(98)00045-X

Losina, E., Weinstein, A. M., Reichmann, W. M., Burbine, S. A., Solomon, D. H., Daigle, M. E., ... \& Jordan, J. M. (2013). Lifetime risk and age at diagnosis of symptomatic knee osteoarthritis in the US. Arthritis Care \& Research, 65(5), 703-711. https://doi.org/10.1002/acr.21898

Moghadam, H. Z., Hoseini, S. T., Hashemian, A. M., \& Sharifi, M. D. (2017). The relation of q angle and anthropometric measures with ankle sprain; a case-control study. Emergency, 5(1).

Quinn, E. (2018). Learn about the $\mathrm{Q}$ angle and potential injuries in female athletes. Retrieved from https://www.verywellfit.com/q-angle-and-injuries-in-women-athletes-3120841

Sojbjerg, J. O., Lauritzen, J., Hvid, I., \& Boe, S. (1987). Arthroscopic determination of patellofemoral malalignment. Clinical Orthopaedics and Related Research, (215), 243-247. https://doi.org/10.1097/00003086-198702000-00035

Teixeira, K. P., Masuyama, N. A., \& Folha, R. A. C. (2008). Ângulo Q e Trato Iliotibial: um estudo de correlação [Trabalho de Conclusão de Curso]. Belém: Universidade da Amazônia.

Woodland, L. H., \& Francis, R. S. (1992). Parameters and comparisons of the quadriceps angle of college-aged men and women in the supine and standing positions. The American Journal of Sports Medicine, 20(2), 208-211. https://doi.org/10.1177/036354659202000220

Yamak, B., İmamoğlu, O., \& İslamoğlu, İ., Çebi, M. (2018). The effects of exercise on body posture. Turkish Studies Social Sciences, 13(18), 1377-1388. https://doi.org/10.7827/TurkishStudies.13911

Yamaner, F., \& İmamoğlu, G. (2018). Sport performance colors power and effect. Turkish Studies, 13(15), 515-526. https://doi.org/10.7827/TurkishStudies.13602

Yılmaz, A. K., Kabadayı, M., Mayda, M. H.,Çavuşoğlu, G., \& Taşmektepligil, M. Y. (2017). Analysis of Q angle values of female athletes from different branches. Ovidius University Annals, Series Physical Education and Sport/Science, Movement and Health, 17(2), 141-147.

\section{Copyrights}

Copyright for this article is retained by the author(s), with first publication rights granted to the journal.

This is an open-access article distributed under the terms and conditions of the Creative Commons Attribution license which permits unrestricted use, distribution, and reproduction in any medium, provided the original work is properly cited. 